\title{
Effect of Three Different Types of Culture Conditions on Spirulina maxima Growth
}

\author{
Maria Paula da Costa Monteiro ${ }^{{ }^{*}}$, Rosa Helena Luchese ${ }^{1}$ and Theresinha Monteiro \\ Absher $^{2}$ \\ ${ }^{I}$ Departamento de Tecnologia de Alimentos; Universidade Federal Rural do Rio de Janeiro; BR 465 km7; 23890 - \\ 000; Seropédica - RJ - Brasil. ${ }^{2}$ Centro de Estudos do Mar; Universidade Federal do Paraná; Av. Beira Mar s/n; \\ 83255-000; Pontal do Sul - PR - Brasil
}

\begin{abstract}
Growth of Spirulina maxima was studied in three types of culture conditions with four replicates each: 1) manual aeration with natural sunlight; 2) manual aeration with artificial light; and 3) constant aeration with an aquarium compressor and artificial light. After 185 days of incubation, growth declined in the first two treatments, while in the third treatment, higher growth was observed with average optical density of 3.7 against 1.8 and 1.9 in the first and second treatment, respectively. This was probably due to the fact that under constant aeration the salts were suspended avoiding the crystallization what could cause a decrease in the availability of the necessary nutrients for the growth. Also, the constant stirring allowed all the cells to receive the same amount of light promoting photosynthesis and consequently, a larger growth and characteristic green coloration. Culture with constant aeration under artificial light should be used for $\mathrm{S}$. maxima_cultivation because, besides reducing labor hours, it could be a more effective method for improving the economic income.
\end{abstract}

Key words: aquarium compressor, biomass production, microalgal growth, Spirulina

\section{INTRODUCTION}

Spirulina is a blue-green mesophile filamentous cyanobacteria, with high protein content, being largely used as a source of single cell protein for humans and animals. These microalgae have been used as part of the diet of people that lived in villages close to Chad lake in Africa (Ciferri, 1983; Medina, 2003). At the time of the discovery of America, in Mexico, the Aztecs that lived close to the Texcoco lake already used Spirulina enriched products (Durand - Chastel, 1993; Costa, 2004).
Spirulina presents high protein content and it has been used as alimentary complement in diets for weigh loss and malnutrition. This is due to the high protein value $(60-70 \%$ in dry weight), vitamin value, mainly vitamin $\mathrm{B}_{12}$, and lipids content (rich in fatty polyunsaturated acids), mainly $\gamma$-linolenic acid (GLA), an antioxidant highly used in medicine (Cozza, 2000; Herrero, 2004).

Presently, there are twenty two companies in the world that produce Spirulina biomass and market it as alimentary supplement. They are also used in Japan in animal feed and extraction of pigments

*Author for correspondence: mpaulamont@uol.com.br 
for use in foods (Belay, 1997; Antelo, 2006).

Several factors have been contributing to the food crisis in the world: high population increase, absence of sound agricultural politics, climatic problems, diseases as the Bovine Spongiform Encephalopathy (BSE) (mad cow disease), and more recently, the chicken influenza.

The production of food through uncommon sources comes as an alternative to increase the food production (Monteiro and Luchese, 2007).

Single Cell Protein (SCP) is cellular material of microbial origin obtained for nutritious purposes (Olsen and Allermann, 1991), and comprises different species of bacteria, filamentous fungi, yeasts and microalgae

Spirulina is a source of SCP used for humans and animals (Rosa, et al. 2006).

The objective of this work was to evaluate the growth of the microalgae $S$. maxima in different light and aeration conditions seeking to reduce the labor for the microalgae production and optimize cost vs. benefit relationship.

\section{MATERIALS AND METHODS}

Monoalgal samples of Spirulina maxima, straight line form, obtained from the UFRRJ's Department of Food Technology, originating from the Center of Studies of Autotrophic Microorganisms of Firenze (Italy) supplied by Dr. Sunao Sato (USP) were used. Three types of culture conditions with four replicates were studied: 1) manual aeration with natural sunlight; 2) manual aeration with artificial light, and; 3) constant aeration using an aquarium compressor and artificial light. Culture conditions were: room temperature, Paoletti's culture media (Paoletti et al, 1975); optical density measured in a spectrophotometer (Spectronic 20, Bausch and Lomb) at $540 \mathrm{~nm}$ (once a month); trichomes size evaluated through observation in an optical microscope.

\section{Manual aeration with natural sunlight}

This experiment was accomplished in $300 \mathrm{~mL}$ glass containers with $100 \mathrm{~mL}$ of cultivation media, closed with plastic covers and placed on a tiled bench, near a window exposed to natural sunlight and stirred twice daily for five consecutive days a week.

\section{Manual aeration with artificial light}

In this experiment, the glass containers $(300 \mathrm{~mL})$ with $100 \mathrm{~mL}$ of culture media, were placed on a tiled bench and the illumination was through two fluorescent lights at $40 \mathrm{~cm}$ distance from the containers, corresponding to $2.4 \mathrm{lux}$, with $8 \mathrm{~h}$ of daily illumination. The containers were closed with plastic covers and stirred manually twice daily for five consecutive days a week.

\section{Constant aeration with artificial light}

Constant stirring were effected with an air compressor used for aquarium aeration (Vigo-air), with capacity of $100 \mathrm{~L}$. The air was filtered through at the exit of the compressor. Glass containers of $500 \mathrm{~mL}$ of capacity were used, with $100 \mathrm{~mL}$ of cultivation media with cotton covers and aquarium hoses adapted with glass stems at its end Illumination was through two fluorescent lights at $40 \mathrm{~cm}$ distance from the containers, corresponding to $2.4 \mathrm{lux}$, with $8 \mathrm{~h}$ of daily illumination, except at weekends.

Table 1 - Synthetic Paoletti's media, to each $1 \mathrm{~L}$ of the macroelements* solution was added $1 \mathrm{~mL}$ of the microelements $* *$ and $1 \mathrm{~mL}$ of the Fe-EDTA*** solutions.

\begin{tabular}{|c|c|c|c|c|c|}
\hline \multicolumn{2}{|c|}{ Macroelements/Conc.g/L* } & \multicolumn{2}{|c|}{ Microelements/Conc. g/L** } & \multicolumn{2}{|c|}{ Fe-EDTA / Conc. g/L*** } \\
\hline $\mathrm{KNO}_{3}$ & 2.5 & $\mathrm{H}_{3} \mathrm{BO}_{3}$ & 2.860 & EDTA - $\mathrm{Na}_{2}$ & 29.80 \\
\hline $\mathrm{K}_{2} \mathrm{SO}_{4}$ & 1.9 & $\mathrm{MnCl}_{2} \cdot 4 \mathrm{H}_{2} \mathrm{O}$ & 1.810 & $\mathrm{FeSO}_{4} .7 \mathrm{H}_{2} \mathrm{O}$ & 24.90 \\
\hline $\mathrm{MgSO}_{4} \cdot 7 \mathrm{H}_{2} \mathrm{O}$ & 0.25 & $\mathrm{ZnSO}_{4} \cdot 7 \mathrm{H}_{2} \mathrm{O}$ & 0.220 & \multicolumn{2}{|c|}{$\mathrm{H}_{2} \mathrm{O}$ dist. s q. $1000 \mathrm{~mL}$} \\
\hline $\mathrm{CaCl}_{2} \cdot 2 \mathrm{H}_{2} \mathrm{O}$ & 0.05 & \multicolumn{2}{|c|}{$\mathrm{Na}_{2} \mathrm{Mo}_{2} \mathrm{O}_{4} \cdot 2 \mathrm{H}_{2} \mathrm{O} 0.390$} & & \\
\hline $\mathrm{K}_{2} \mathrm{HPO}_{4}$ & 0.5 & $\mathrm{CuSO}_{4} .5 \mathrm{H}_{2} \mathrm{O}$ & 0.079 & & \\
\hline $\mathrm{NaHCO}_{3}$ & 15.15 & $\mathrm{Co}\left(\mathrm{NO}_{3}\right)_{2} \cdot 6 \mathrm{H}_{2} \mathrm{O}$ & 0.049 & & \\
\hline $\mathrm{Na}_{2} \mathrm{CO}_{3}$ & 8.9 & $\mathrm{H}_{2} \mathrm{O}$ dist. s q. 10 & $000 \mathrm{~mL}$ & & \\
\hline $\mathrm{NaCl}$ & 0.92 & & & & \\
\hline \multicolumn{2}{|c|}{$\mathrm{H}_{2} \mathrm{O}$ dist. s q. $1000 \mathrm{~mL}$} & & & & \\
\hline
\end{tabular}




\section{Culture media}

Culture medium used was the synthetic Paoletti's media (Paoletti et al., 1975) (Table 1).

\section{Evaluation of the cellular growth and purity of} the culture

The cellular growth was measured by the optical density using a spectrophotometer (Spectronic 20, Bausch and Lomb) $540 \mathrm{~nm}$ once a month. The purity of the culture was evaluated through the observation of $S$. maxima trichomes in optical microscope.

\section{Data analysis}

Differences in the microalgae growth in the experiments were analyzed through the Analysis of Variance (ANOVA) at the significance level of $\alpha=0.05$.

\section{RESULTS AND DISCUTION}

The mean values of the optical density are shown in Table 2.
Highly significant differences in microalgal growth was observed among the treatments and days $(\mathrm{p}<0.05) \quad($ Table 3$)$, but not among the replicates of each experiment ( $p>0.05$ ).

There was no contamination during the experiment.

At the end of the incubation period (185 days), the trichomes of treatments 1 and 2 were yellowish, thin and brittle, indicating that the culture was dying. Figure 1 shows the growth curves with the largest growth observed for treatment 3 ; under the other two conditions, the growth already in decline. This was probably due to the fact that under constant stirring, the mineral salts present in the medium did not crystallize, as in the other two cultivation conditions, causing a decrease in the necessary nutrients for growth. Another factor that favorably affected the microalgal growth was the illumination, since constant circulation kept the algal cells in suspension, thus allowing them to receive the same amount of light exposing as much surface area as possible to the light, promoting the photosynthesis, and consequently, better growth and characteristic green coloration

Table 2 - Mean values of absorbance $\left(\mathrm{A}_{540 \mathrm{~nm}}\right)$ obtained at the four replicates of the three different culture conditions. Treatment $1=$ manual aeration with natural sunlight; Treatment $2=$ manual aeration with artificial light; Treatment $\underline{3=\text { constant aeration with artificial light. }}$

\begin{tabular}{cccc}
\hline Days & Treatment 1 & Treatment 2 & Treatment 3 \\
\hline 0 & 0.04 & 0.04 & 0.04 \\
31 & 0.42 & 0.42 & 0.55 \\
59 & 0.68 & 0.68 & 1.11 \\
92 & 1.19 & 1.10 & 1.77 \\
125 & 1.73 & 1.70 & 2.52 \\
157 & 2.68 & 1.90 & 2.73 \\
185 & 1.77 & 1.90 & 3.68 \\
\hline
\end{tabular}

Table 3 - ANOVA results of Spirulina maxima growth in the three treatments and four replicates.

\begin{tabular}{cccccc}
\hline Source of variation & Sum of Squares & Degrees of Freedom & Mean Squares & F $_{\text {obs }}$ & P value \\
\hline Treatment & 7.114 & 2 & 3.557 & 18.261 & $0.000^{*}$ \\
Replicates & 1.533 & 3 & 0.511 & 2.623 & 0.057 \\
Days & 66.934 & 6 & 11.155 & 57.266 & $0.000^{*}$ \\
Error & 14.025 & 72 & 0.194 & & \\
\hline
\end{tabular}

*Highly significant difference $(\mathrm{P}<0.001)$. 


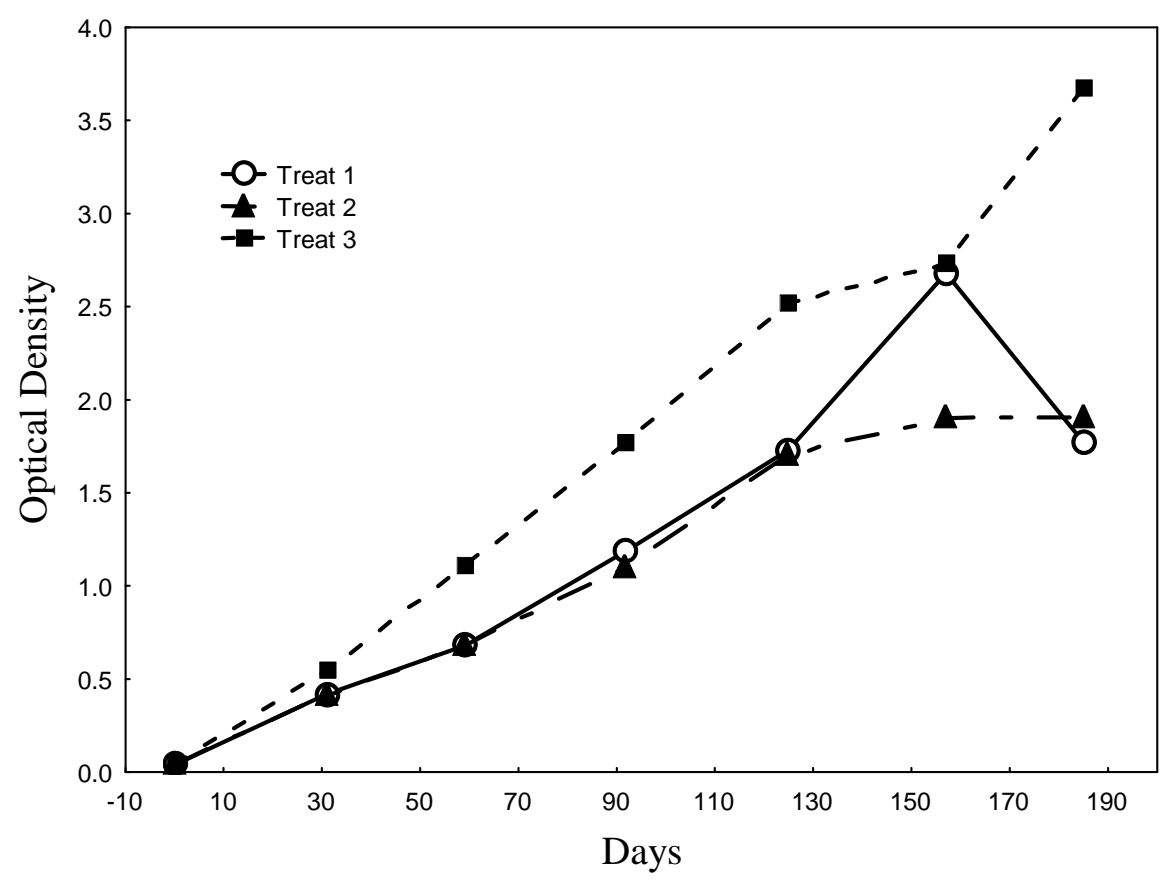

Figure 1 - Spirulina maxima growth curves in the three experiments with values of optical density measured in absorbance. Treatment $1=$ manual aeration, with natural sunlight; Treatment $2=$ manual aeration, with artificial light; Treatment $3=$ constant aeration with artificial light. Values represent averages of four replicates.

The results obtained here, were comparable with Salles et al. (2003) that evaluated the growth of $S$. platensis in alkaline solution of ashes of sugarcane bagasse as nutrients source, obtaining an absorbance of $c a 0.9$ after 8 days of incubation.

It could be concluded that the use of an aquarium compressor was not only viable, but advisable, because, besides reducing labor, it was more effective, improving economics.

\section{RESUMO}

O crescimento de Spirulina máxima foi estudado em três condições de cultivo: 1) agitação manual com iluminação natural; 2) agitação manual com iluminação artificial e; 3) agitação constante feita por compressor de aquário e iluminação artificial. O maior crescimento foi observado nesta última condição, onde após 185 dias foram observados valores médios de densidade ótica de 3,7 enquanto, valores de 1,8 e 1,9 foram obtidos no primeiro e segundo experimento, respectivamente. Diferentemente do ocorrido com os outros tratamentos, não foi observado declínio no crescimento após 185 dias, o que foi atribuído ao fato de que, sob constante agitação os sais ficam suspensos e não cristalizam, fato que acarretaria diminuição da disponibilidade de nutrientes necessários ao crescimento. Também a agitação constante permite que todas as células recebam a mesma iluminação, promovendo fotossíntese e consequentemente um maior crescimento e coloração verde característica. Conclui-se que o emprego do compressor de aquário é não somente viável, mas recomendável, pois além de diminuir a mão de obra ainda se mostrou mais eficaz, melhorando o rendimento.

\section{REFERENCES}

Antelo, F.S.; Santos, L.D.; Quiness, L.K.N.; Anschau, A.; Costa, J.A.V. and Kalil, S.J. (2006), Caracterização da C-ficocianina de Spirulina platensis estudo da cinética da desnaturação da proteína. Resumos XX Congresso Brasileiro de Ciências e Tecnologia de Alimentos,. 08-11 Outubro, Curitiba, p. 0284. 
Belay, A. (1997), Mass culture of Spirulina in outdoors - The Earthrise Farms experience. In-Spirulina platensis (Arthrospira): Physiology, Cell-biology and Biotechnology, ed A. Vonshak,. Taylor and Francis, London

Ciferri, O. (1983), Spirulina, the edible microorganism (algae, single-cell protein). Microbiol. Rev. 47 (4), 551-578

Costa, J.A.V.; Colla, L.M. and Duarte Filho, P.F. (2004), Improving Spirulina platensis biomass yield using a feg-batch process. Bioresource Technology 92, 237-241

Cozza, K.L and Costa, J.A.V (2000), Lipídeos em Spirulina . Vetor, 10, 69-80

Durand-Chastel, H. (1993), La Spiruline, Algue de Vie. In-Spiruline Algue de Vie eds F. Doumenge, $\mathrm{H}$. Durand-Chastel and A. Tpulemont, Bulletin de L'Institut Océanographique. Monaco, No Esp.12, 712

Herrero, M.; Ibañez, E.; Señoráns, J. and Cifuentes, A. (2004), Pressurized liquid extracts from Spirulina platensis microalga determination of their antioxidant activity and preliminary analysis by micellar electrokinetic chromatography. Journal of Chromatography A. 1047, 195-203.

Medina M.; Gastón, A.; Abalone, R. and Lara, M.A, (2003), Modelización Térmica de estanques para production de la espirulina (Arthrospira platensis) Avances en Energias Renovables y Medio Ambiente. Argentina $\mathrm{Vol} 7 \mathrm{n}^{\circ} 2$

Monteiro, M.P.C. and Luchese, R.H. (2007), Otimização do crescimento de Spirulina spp. Revista Higiene Alimentar Vol. 21 n 150 p. 464
Olsen, J. and Allermann, K. (1991), La biomasa microbiana como fuente de proteína. InBiotecnologia basica. eds J. Bu'lock and B. Kristiansen. Acribia, Zaragoza

Paoletti, C., Pushparaj, B. and Tomaselli, F.L. (1975), Ricerche sulla nutrizione minerale di Spirulina platensis. Atti XVII Congr. Naz. Soc. It. Microbial. Padova, 26-28 ottobre, vol.2,845-853

Rosa, P.C.; Carvalho, L.S.; Goldbeck, L.; Costa, J.A.V; Schossenke, D.; Touey, J. and Soares, L.A.S. (2006), Formulação de ração enriquecida com a microalga Spirulina e avaliação do perfil dos ácidos graxos de alevinos de carpa húngara. Resumos XX Congresso Brasileiro de Ciências e Tecnologia de Alimentos, 08-11Outubro, Curitiba, p. 0508

Salles, M.S.V.; Duarte, R.M.T. and Lacaz-Ruiz, R. (2003), Avaliação da solução alcalina de cinzas de bagaço de cana-de-açúcar como fonte de nutrientes para Spirulina spp. p 123-130 In- Espirulina: Estudos and Trabalhos, coordenador R. Lacaz-Ruiz, Roca, São Paulo. 